\title{
Multicultural Learning Tolerance in Raising Awareness of Students' Attitude
}

\author{
Rasimin \\ State Islamic Institute (IAIN) Salatiga \\ Salatiga, Indonesia \\ rasimin75@gmail.com
}

\begin{abstract}
Multicultural learning will give equal opportunities for everyone regardless of gender, social class, ethnicity, race, religion, and cultural background students. Its stages are carried through the self-exploration study, exploration results presentation, peer group analysis, expert opinion, and reflection. Indonesia has socio-cultural diversity people who form a society. From that society, the diverse culture was formed. Everyone must appreciate and respect the culture in the community. Whatever the form of a culture, it must be acceptable to everyone without discriminating among one culture and another. Tolerance attitude as a form of behavior leads to an open attitude and respect the differences, such as race, color, language, indigenous customs, culture, language, and religion. These are all fitrah and sunnatullah that have become the decree of God.
\end{abstract}

Keywords-Education, Multicultural, and Tolerance

\section{INTRODUCTION}

One of the learning objectives in college is to improve the competencies of students, such as affective, cognitive, and psychomotor. Through those competencies, the students are able to increase their thought, act, and behavior in the society. In these conditions, according to the characteristics of social science, it is closely related to the symptoms of daily social life. The lectures are demanded to be able to find and apply the appropriate learning in order to achieve the learning objectives.

According to the Act No. 20 Year 2003 on the National Education System clearly stated that education is a conscious and planned effort to create an atmosphere of learning and learning process in order to learners actively develop their potential to have spiritual power, self-control, personality, intelligence, noble, as well as the skills that required to himself, society, nation and state (UUSPN: Article 3 paragraph 1). Therefore, education is expected to produce a complete human that is developing the whole person, all in affective aspects, cognitive aspects, and psychomotor aspects so that the students can face the various challenges in their life. Ref [1] stated that the complexity of learning required the appropriate strategies for managing the learning in the classroom. The components are: (1) learning objectives; (2) student background; (3) content and material structure; (4) the cost of teaching; and (5) facilities.

In practice, education is currently seen as a symptom of a decrease in potential development due to the learning process tends to focus on the teacher [2]. Learning only presents the knowledge that must be memorized and known to learners [3]. Even this phenomenon is also seen in college.

Indonesia is one of the largest multicultural countries in the world [4]. These conditions are likened to fires in chaff, which may at times can cause conflicts due to the heat of the political, religious and socio-cultural temperatures, so that it required an inclusive-pluralist, multicultural-humanist, and dialogue-persuasive view. Multicultural education is an offer of educational concepts with the diversity of ethnic, cultural, linguistic, religious, social status, genders, abilities, and age in society. Multicultural education is the unity of the concept of a continuous educational reform movement to strengthen Indonesian nationalism that can bring the nation towards a complete Indonesian perspective, with the distinctive features of each community group that still preserved.

In the context of Indonesia motto "Bhinneka Tunggal Ika" is applied one-sidedly. The spirit of uniformity is more prominent than the spirit of diversity in the management of a country. A very plural society is often falling into instability that is vulnerable to disintegration, and even there is no guarantee of centralized politics can unite disintegration potential. National education that has the mission of enlightening the life of the nation and responding to global developments demands the education institutions must always improve the quality to produce professional and competitive graduates. These conditions encourage the direction of education policy that refers to the three pillars [5], namely: (1) expansion and equitable education services quality; (2) improving the quality of learning and educational institutions; and (3) improvement and capacity of education services. Based on those pillars, the institution is expected to be able to answer the challenges and global competition in seizing the national and international work market.

Social phenomenon is often found by the students in the environment where the learning resources that can be used in the learning process are one of the appropriate solutions to 
answer this problem. It required a strategy and a planned approach so that the learning can develop student competencies, such as in affective, cognitive, and psychomotor for students with social phenomena in the student residence as a source of learning.

The arguments of this idea in order to optimize the learning process [6], namely: (1) the multicultural learning is intended to support in creating a learning environment where students engage in practice and sustainable activities; (2) the learning are not one-way learning; and (3) the learning will be functional if it based on the student's socio-cultural background in real terms.

\section{LITERTURE REVIEW}

Taylor [7] explained that education, culture, and civil society Indonesia are a complex whole of knowledge, belief, art, morals, law, customs, and also the abilities and habits that gained by human beings as members of society. Therefore, the learning process cannot be separated from the elements of the culture. Thus, this culture is seen as a guide or direction of the humanization process to humanize human, and the appreciation of the dignity and human dignity as individual and social creatures. In learning, it also needs another multidisciplinary view of sociology, anthropology, psychology, communication, biology, etc.

Meanwhile, in the broadest understanding, multicultural education is actually inseparable from the socio-cultural conditions of the diverse communities of tribes, religions, and races that in social reality live side by side with one another. In the Encyclopedia of Wikipedia entitled American Civil Rights Movement (1955-1968), the discourse of the emergence of multi-cultural education cannot be separated from the events of civil rights movement that occurred in the 1960s in America, because of the practice of life that is discriminatory [8].

Multicultural education is an educational concept that has three important things: (1) all learners are the target groups in the educational process, without considering the background of learners; (2) oriented to the differences of learners; and (3) integration as the primary goal. Even in the year 1998, the discourse of multicultural education began to echo in Indonesia. The discourse is seen a variety of discussions, seminars and workshops, research, publishing books, and journals are nuanced multicultural. This is based on the fact that Indonesia is a country that has many problems about the existence of social, ethnic, and religious groups is very diverse.

The discourse is stronger due to uniformity efforts in various aspects of life that was done during the Orde Baru government. The management of the state with an emphasis on the spirit of uniformity is rather than the enthusiasm of the spirit of diversity coloring the concepts and practice of education in Indonesia.

Based on these conditions, it is necessary to reconstruct the Indonesian national culture which can be an integrating force that can bind all existing ethnic and cultural diversity. In addition, the formation of a democratic Indonesian multicultural society cannot be taken for granted or trial and error. However, it must be pursued systematically, programmatically, interactively, and continuously. The most strategic step is through multicultural education in educational institutions, both formal and informal [9] [10].

In the multicultural society conditions such as in Indonesia, the application of multicultural education is an urgent necessity. Moreover, the multicultural education can equip learners to be willing to take other groups as unity, regardless of cultural, ethnic, genders, linguistic, or religious differences. The demands for the importance of multicultural education receive a positive response from the executive and legislative. This is evidenced by the enactment of the [11], which accommodates human rights values and a multicultural spirit. In fact, these values serve as one of the principles of the implementation of National Education, as set forth in Chapter III of Article 4, namely: education is held democratically and equally and not discriminatively by upholding human rights, religious values, cultural, and diversity of the nation [12].

It is clearly understood that there is a significant relationship between multicultural education, social concepts, and community culture. For example in the United States, Canada, and Australia that have multicultural societies, the original inhabitants are a minority and the majority of other residents are migrants from other countries, so the concept of multicultural education is quickly accepted by the people. On the other hand, the countries such as Britain, Germany, France and the Netherlands that are colonial countries that are not as fast as in the United States, Canada, and Australia to accept the concept of multicultural education. Thus, it can be understood that colonial countries have a discriminatory habit against their colonies.

There are several terms related to multicultural education. The term is commensurate with multicultural education, namely: "interethnic education, transcultural education, multiethnic education, and cross-cultural education" In addition, Driel [15] called it the term "human rights education and intercultural education". While the UNESCO calls it with the term intercultural education and inclusive education.

Some of the terms above have the same meaning, namely an educational concept that provides equal opportunities to all learners. The term is commonly used in many countries such as Europe, Australia and Indonesia are intercultural education, multicultural education, and inclusive education. The first two concepts point to equal opportunities in order to educate the learners with diverse cultural and ethnic backgrounds. Meanwhile, the last concept refers to provide equal opportunity in order to obtain education for all learners regardless of the physical, intellectual, social, emotional, language, and other conditions.

However, the term that is used in this study is multicultural education. The reasons for using this term are: (1) multicultural education is more popularly used in many countries of the world, rather than the term intercultural education and inclusive education; and (2) Theoretically and practically, the term multicultural education has an adequate 
reference, rather than the term intercultural education and inclusive education.

Etymologically, the term multicultural education consists of two words, namely education and multicultural. The word education, in some references is defined as the process of developing the attitude and behavior of a person or group of people in an effort to mature the human beings through the efforts of teaching, training, process, deeds, and ways of educating [14]. Meanwhile, the multicultural word comes from two words, namely multi and culture. In general, multiwords mean a lot, diversity, or variety. Meanwhile, the word culture has some meaning, namely culture, civility, and maintenance. Thus, multicultural interpreted cultural diversity as a form of diversity in someones background. Etymologically, multicultural education is defined as education that takes into account the cultural diversity of the learners.

The other side of multicultural education provided equal opportunities to all learners of different cultural backgrounds to obtain education, both at school and at college [15]. The Baker's definition is different from the definition of multicultural education formulated by Banks. If the Banks's definition is more emphasized on aspects of ideas, concepts, and ideas about multicultural education, then the Baker's definition is more emphasizing on aspects of movement and struggle for realizing the ideas and ideas of multicultural education in practice.

Ref [18] stated that multicultural education is a free study of racism, sexism, and other forms of social and intolerant dominance. According to this definition, Hidalgo limits multicultural education to only aspects of the classroom learning process democratically, whatever the cultural background learners will gain equal rights and treatment from educators and all learners are entitled to be actively involved without feeling superior or inferior.

In the learning process, they also have the same right to get the attention of the educators. Therefore, the learning process in multicultural education will provide opportunities for the learners with specific cultural backgrounds to feel superior to other learners because of different cultural backgrounds. Multicultural education is an education that helps learners to develop their ability to know, accept, appreciate, and feel the cultural diversity [17] [20] [21] [22].

According to this definition, multicultural education is broader, in limitless meaning to one aspect of education, but it covers all aspects of education, such as aspects of educators, learners, objectives, materials, curriculum, methods, and evaluation. In this connection, all aspects of education should be directed towards developing the learners in order to recognize, accept, and appreciate the cultural diversity that exists in the school. In other words, the ability of the learners to recognize, accept, and appreciate cultural diversity can be developed through the formulation of objectives, materials, and methods of learning.

\section{A. Learning to Live Together}

In cultural diversity (language, ethnicity, and a way of life, art, morals, and customs) became the basis of enrichment in learning so that it could create a learning process to live together in peace and harmony.

The conflict that has happened so far is also often based on prejudices on races, ethnicity, religion and the gap between the rich and the poor. Therefore, education is required to equip the students not only on the mastery of science and technology from the ability to work and solve problems but also the ability to live together with different people with a full tolerance, understanding, and without prejudice.

The concept of learning to live together as described by [21] that in one pillar of learning by UNESCO there are four things as follow. The first is learning to know means education is essentially an effort to seek to find out the required information and useful for life. Learning to know in the process not only knows what is meaningful but also at the same time knows what is not beneficial for his life. In order to implement learning to know, the teacher must be able to put himself as a facilitator. In addition, the teachers are required to be able to play a double role as a friend to dialogue for the students in order to develop mastery of the student knowledge.

The second is learning to be means education is also a learning process to do something. The learning process produces changes in the cognitive aspect, the competence enhancement, as well as the conscious selection and acceptance of values, attitudes, rewards, feelings, and the willingness to act or respond to a stimulus. Education is not only to give person knowledge about something, but also to give further skillfully to do or do something in order to produce something meaningful for life. Schools as a learning place for communities to study should facilitate their students to actualize the skills which they possess, as well as their talents and interests in order to make the "Learning to do" (learning to do something) can be achieved. Although the talent and interest of children are affected by heredity, the growth and development of their talents and interests also depend on the environment. As we all know that skill is a means to sustain someone's life and even the skill is more dominant than the mastery of knowledge.

The third is Learning to be or learning to be something. Mastery of knowledge and skills are part of the process of becoming our own self (learning to be). This is closely related to the talent, interest, physical development, psychology, personal typology of children and their environmental condition. For example: for aggressive students, they will find their true identity when given a wide enough opportunity to be creative. And vice versa for passive students, the roles of teachers as a compass direction as well as a facilitator are needed to develop and improve the students' self-potential as a whole and maximum. Being our own self is defined as a process of understanding of needs and self identity. Learning to behave according to the norms and rules that apply in society, learning to be a successful person, is actually a process of achieving self-actualization. 
The fourth is learning to live together (learning to live together). In this fourth pillar, the habit of living together, mutual respect, openness, giving, and receiving needs to be developed in schools. These conditions enable the growth of mutual understanding between races, ethnicity, and religion. With the ability possessed, as a result of the educational process, it can be used as a preparation to be able to act in an environment where the individual is located, and also be able to put their own self based on their role. An understanding about the role of self and others in the study group is a provision in socializing in the community (learning to live together). As a matter of fact, education in Indonesia should be aimed at improving the quality of intellectual and professional skills as well as attitude, personality, and morale. With the ability and attitude of such Indonesian then in its turn, it will make the people of Indonesia become dignified society in the eyes of the world community.

\section{B. The Focus Of Multicultural Learning}

According to [22], instruction or learning is a system that aims to assist student learning process, which contains a series of designed events and is arranged in such a way to influence the occurrence of the students learning process becomes internal. As [23] describe that there are six effective learning characteristics, which are namely: (1) the student becomes an active reviewer of his environment by observing, comparing, finding similarities and differences and forming concepts and generalizations based on the exist similarities, (2) the lecturer provides the material as the focus of thinking and interaction in the course, (3) the students' activities are entirely based on the assessment, (4) the lecturer is actively involved in providing the direction and guidance to the students in analyzing the information, (5) the learning orientation is about the learning context material mastery and the thinking skill development, and (6) lecturer uses learning models that vary according to the purpose and teaching style of the lecturer. Learning is an interactive-communicative process between learning resources, lecturers, and students which results in exchanging information.

The focus of multicultural learning is stressing more about the peace issue, the human rights (HAM), and democratization with the components of educational nature, namely: (1) education is a continuing and sustainable process, (2) educational process means growing the human's existence, (3) the human's existence is socializing, (4) the cultured educational process in the society, (5) there is a dimension of space and time (historicity, present and future vision). Multicultural education focuses on three concepts [26], which are: (1) the study of ethnicity; (2) the study of injustice; and (3) study of the learning process.

\section{Multicultural Learning Stages}

Learning is an instrument that is very strategic in determining the success of the teaching-learning process. Its existence can directly provide its own dynamics for the students to absorb and understand the material content and the materials instructional explanation delivered by the teachers. The learning process will effectively run if it is supported with the availability of adequate facilities. The provision of learning facilities with the process of its management which are dynamic, conducive, interactive dialogs, and motivating is very important and needed for the exploration and development of the learners' potential optimally. It is because their potential is triggered by some auxiliary facilities that support the process of educative interaction. The learning process seems to be in factual realm or it should be able to be seen by eyes. This learning process which is dynamic, conducive, interactive dialogs, and motivating is difficult to achieve with the performance of teachers who simply just rely on the ability to speak without looking at other aspects whichare more strategic in influencing the learners. Concerningon the teachers' speaking ability usually gives negative impacts on the communication process with the learners. Communication barriers in the learning process are as follows:

First, verbal, it means that the learners can mention the words but do not know the meaning of the words. This happens because the teacher usually only teaches with oral explanation (lecturing), so the learners tend to mimic what the teacher says. It can be worse when learners feel afraid to use other words even though it is identical to develop the words into a good sentence. In the learners' mind, it is already imprinted that the teacher's words is the most correct.

Second, false perception, it means that the same terms or words are meant differently by the learners. It usually happens when the teacher only explains orally without using various learning techniques and strategies. The further impact is that if this misperception is brought into the life of the learners, it is feared that they will cause a lack of synchrony between knowledge and solutions of the problems they face. From this situation, it can lead the occurrence of a condition where finally the teachers who became the main pillar in accepting the blame from the parties who do not understand it well.

Third, unfocused attention, it can happen because of several reasons, such as the learners are day-dreaming, the teaching style of the teachers is boring, the teachers present learning materials without variation, the learners are lack of supervision and guidance by the teachers, and etc. Clearly, every less interesting learning process will cause the learners' concentration do not focus on the material and the students 'physical is in the classroom but their mind hovering according to their own imagination.

Fourth, the understanding is not appropriate or not integrated; it means that the learners lack logical and psychological significances. What the students have observed and have experienced occur separately so there is no logical thought process from the awareness until the emergence of concepts. This is what causes the knowledge acquired by the students cannot be stored for long period of time. Their memory is usually constrained by symbols that should be used as a bind between prior knowledge and new knowledge. Another problem that occurs is that the understanding cannot be used to overcome the problems of life 
which are faced by the learners, both at the studying time and when fully grown, or both living individually and living in the society.

Ref [27], identified that there are four dimensions of multicultural education that are expected to assist educators in implementing some programs that are able to respond to the diversity of learners, which are:

The first dimension is the content integration. This dimension is used by educators to provide information with the learning key point that reflecting on different contents. In particular, the educators incorporate the content of learning materials into the curriculum with several different perspectives. Besides that, the lesson plans and learning units are not changed.

The second dimension is the reduction of prejudice. Educators make a lot of efforts to help the learners develop positive behaviors about group differences. The aimed condition is the learning materials should have positive image about the differences in groups and use the learning materials consistently and continuously.

The third dimension is equitable education dimension (equitable pedagogy). This dimension notices the ways in changing the learning facilities so that it can make easier in achieving the learning outcomes in a number of students from various groups. Learning strategies and activities that can be used as effort to treat the education to be fair can be achieved by using the cooperation method (cooperative learning), and it is not by using competitive ways (competition learning).

The fourth dimension is the empowering school culture and social structure. This dimension is important in empowering the culture of the learners that are brought to school from different groups. Besides, it can be used to construct the social structures (school) that harness the diverse cultural potential of the learners as the characteristic of local school structures, for example in relation to the group practice, social climate, exercises, extra-curricular participation and staff reward in responding to the differences that exist in the school.

Each learning model emphasizes the excellences in pursuing the goals that each of its development believes, but for practical application in a very different place may need to be adjusted to the ability with the various aspects with all the limitations of existing conditions because, of course, it must not be the same. At least it should be known where, by whom, or with whom and especially for whom the learning process is conducted. Specifically related to the learning needs of the student's growth, from a number of models, it can certainly be suggested or referred to the learning model that can be used as the reference which is the model of Cognitive Emotion and Social Development. The basic view is that the students are product of various influences, ranging from their family, health, socio-economic conditions and school. Each approach in the theoretical views is related to its stressing, in practical it can be related between approaches with other approaches simultaneously. Therefore, it is important to fulfill the operational technical needs in developing the learning of
Social Knowledge based on value approach in particular way. The followings are technical step picked of several choices models which are considered to represent the demands of material characteristics, the learners and social setting become the culture environment. A lecturer in performing his or her duties cannot leave is called as learning model and its application in the classroom. To improve the understanding of various learning models, it needs to pay attention to some models of learning.

The stages done in multicultural learning model are: first, self exploration study. It is the learners' potential socio-culture environment with multicultural substance that assigns the learners to conduct local exploration, which includes themselves and socio-cultural environment. The next is exploration of the presentation results. The learners present the results of exploration (can be individual or group) on the socio-cultural issues (local) which are interesting for them in front of their friends or other groups. The second is peer group analysis. The other friends or other learners, who have been divided into several groups, are requested to analyze and give comments on the exploration results presentation of the chosen problem. Each learner or group presents the result of their analysis result one by one. The third is expert opinion. The educators give comments on the exploration results which are presented and some comments and some comments are also given by other learners. The fourth is reflection. The last stage is recommendation and commitment building from the educators together with the learners by views the reflection of the learners on the advantages of the local socio-cultural values that is estimated to have the potential and prospects in building the value commitments that can be used as an adhesive of unity and integrity of the local life and national life.

\section{College Students Tolerance}

The students are members of society who try to develop their potential through learning process that is available on the track, level, and certain types [12]. Every child has a different creativity potential and it should be developed, which is through a learning process that is assisted by teachers or educators. In its development, the child will be influenced by the family, school, and society. Djamarah defined that the college students are every person who receives the influence of another person or group of people who run the educational activities [26]. The students can be considered as key of the educative interaction, as potential human being, then in their self there is a power that can grow and develop along their age.

Tolerance leads to an opened attitude, and willingness to confess the existence of various differences, in terms of race, skin color, language, indigenous customs, culture, language, and religion. All of them are nature and sunnatullah or God's laws that have become the statute of God. All humans cannot resist to this sunnatullah. Thus, for humans, it is proper to follow the instructions of God in facing those differences. The tolerance between different religious communities belongs to one of important treaties that exist in the system of Islamic theology. It is because the God always reminds us about the 
diversity of human beings, all in terms of religion, race, skin color, indigenous customs, and etc.

The college students as the nation potential successor in protecting and preserving the existence of tolerance can be achieved by certain ways such as interweaving relationship or friendship in good way and scheduling the security of worshiping places every time there are religious events or religious holy days. An explanation of the security agenda of worshiping places that have been scheduled is when there is a big event such as the celebration of Christmas as the great day Christians, so that other people from other religions also have a role in maintaining the implementation of the worshiping event.

Vice versa, when Muslims celebrate the Islamic big day, such as Eid al-Fitr and Eid al-Adha day, the religious adherents of Christian, Buddhist and others will participate to keep the implementation of Muslims' worshiping event. The harmony that occurs in Sibolga is one of many ways that can be used to preserve the sense of tolerance. Besides the tolerance among religion diversity, the society will also do mutual respect to the existed culture diversity. The form of tolerance preservation in Indonesia diversity is not only conducted by the community itself but also conducted by religious groups such as community organization.

\section{CONCLUSION}

Indonesia as one of the largest multicultural country in the world that has diverse society needs the existence of pluralist inclusive, humanist-multicultural, and persuasive dialogist point of views. In order to realize a peaceful and harmonious society in life, multicultural education is an offer of educational concepts with the use of the diversity ofethnic, culture, language, religion, social status, gender, ability, and ages in the society.

In the cultural diversity, the language, ethnic, lifestyle, art, morals and customs will be the basis of enrichment in the learning process, so that it can create the learning process to live together in peace and harmony. The conflicts that have often occuredare mostly based on the prejudice of races, ethnics, religions and between the rich and the poor. Therefore, the bias multicultural learning of students is not only focused on the science and technology mastery of the ability to work and solve problems, but also the ability to live together with different people with tolerance, mutual respect, and without prejudice.

Tolerance leads to an opened attitude, and willingness to confess the existence of various differences, all in terms of race, skin color, language, indigenous customs, culture, language, and religion. All of them are nature and sunnatullah or God's laws that have become the statute of God so that all humans cannot resist to this sunnatullah.
[2] A. Spanos, Probability theory and statistical inference: econometric modeling with observational data, Cambridge University Press, 1999.

[3] L. O. J. Gaffar, "Pengantar keperawatan profesional," EGC, Jakarta, 1999.

[4] A. Aly, Pendidikan Islam Berwawasan Multikultural, Yogyakarta: Bina Insani Press, 2004

[5] J. Hasbullah, Social Capital: menuju keunggulan budaya manusia Indonesia, MR-United Press, 2006.

[6] G. E. Peterson, Decentralization in Latin America: learning through experience, World Bank Publications, 1997

[7] H. A. R. Tilaar, Paradigma baru pendidikan nasional, Rineka Cipta, 2000 .

[8] P.C. Gorski, A brief history of multicultural education, Published on 1999, in http://www. edchange. org/multicultural/papers/edchange_history.html, 1999

[9] M. Moeliono, "Adat and globalization: Living apart together," In Paper submitted for the International Association for the Study of Common Property 9th Biennial Conference, Victoria Falls, Zimbabwe, 2002.

[10] D. R. Sugiyono, "Metode Penelitian Administrasi," Bandung: Alfa Beta, 2002.

[11] Act No. 20 Year 2003 on the National Education System

[12] UU Nomor 20, "Tahun 2003 tentang," Sistem Pendidikan Nasional 1, no. 2 (20): 3.

[13] L.H. Ekstrand, "Multicultural Education" dalam International Encyclopedia of the Sociology of Education, New York: Pergamon, 1997

[14] A. Dawam and S. Alafsana, " Emoh" sekolah: menolak" komersialisasi pendidikan" dan" kanibalisme intelektual", menuju pendidikan multikultural, Inspeal Ahimsakarya Press, 2003.

[15] J. A. Baker, "Teacher-student interaction in urban at-risk classrooms: Differential behavior, relationship quality, and student satisfaction with school," The elementary school journal 100, no. 1, 1999, pp.: 57-70.

[16] F. Hidalgo, Multicultural Education landscape for Reform in the Twently-first Century, New York: Pergamon, 1988

[17] P. Suparlan, "Ethnicity and Its Potential for Social Disintegration in Indonesia," Communal Conflicts in Contemporary Indonesia, Konrad Adenauer Foundation, Pusat Bahasa dan Budaya IAIN Syarif Hidayatullah: Jakarta, 2002, pp. 101-115.

[18] P.G. Ramsey, History and Trend of Multicultural Education, New York: NY Cotinuum, 2008

[19] B. Yoon, Guest Editor's Introduction: Multicultural Education in Middle Grade Settings, Midle Grades Research Journal Vol. 7. No. 2, 2012.

[20] C. Mahfud, Pendidikan multikultural, Yogyakarta: Pustaka Pelajar, 2010

[21] D. B. Rao, International Conference on Learning to live Together, Discoveri Publishing House, New Delhi, 2005

[22] R. M. Gagne, L. J. Briggs, and W. Wager, "Principles of instruction design," Holt Rinehart and Winston, New York, 1979.

[23] P. D. Eggen and D. P. Kauchak, Educational psychology: Windows on classrooms (5th ed.), Upper Saddle River, NJ: Prentice Hall, 2000

[24] J. A. Cardinas, Multicultural Education: A Generation of Advocacy, America: Simon \& Schuster Custom Publishing, 1975

[25] A. J. Bank, Multiethnic Education Theory and Practice, Allyn an Bacon. Inc: Boston, 1981

[26] S. B. Djamarah, Guru dan anak didik dalam interaksi edukatif, Rineka cipta, 2000.

\section{REFERENCES}

